\title{
Synthetic Detergents (Surfactants) and Organochlorine Pesticide Signatures in Surface Water and Groundwater of Greater Kolkata, India
}

\author{
Naresh C. GHOSE ${ }^{1}$, Dipankar SAHA ${ }^{2 *}$, Anjali GUPTA ${ }^{3}$ \\ ${ }^{1}$ Department of Geology, Patna University, Patna, India \\ ${ }^{2}$ Central Ground Water Board, Patna, India \\ ${ }^{3}$ Department of Chemistry, B. S. College, Danapur, India \\ E-mail:dsaha002@yahoo.com \\ Received June 15, 2009; revised July 6, 2009; accepted July 16, 2009
}

\begin{abstract}
An assessment on the concentration of surfactants and pesticides of chlorinated hydrocarbon group in surface and groundwater, is made from Greater Kolkata located in the Western Ganga Delta, one of the largest urban agglomerate in Asia. Concentration of both anionic synthetic detergents and organochlorine pesticide residues analysed from 54 and 19 sampling stations covering groundwater and surface water sources respectively, are generally found to be within the tolerance limit for human consumption. The concentration of synthetic detergent ranges from 0.084 to $0.425 \mathrm{mg} / \mathrm{l}$. Residues of organochlorine pesticides are analysed from

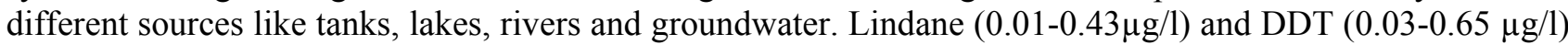
are the most widely detected pesticide residues. Howerer, the two have not exceeded the limits for drinking anywhere. High value of aldrin and dieldrin $(0.9 \mu \mathrm{g} / \mathrm{l})$ is obtained in the river Hugli at Barakpur-Seoraphuli, $20 \mathrm{~km}$ north of Kolkata. Likewise high value of Heptachloreis detected in a canal water sample at Palta $(0.05$ $\mu \mathrm{g} / \mathrm{l}$ ), a suburban area. Seasonally, the pesticide concentration in surface water is maximum during winter due to their higher application and minimum during monsoon. In groundwater, however, this relationship is reverse due to higher infiltration of surface water during monsoon.
\end{abstract}

Keywords: Kolkata, Ganga Delta, Surface Water, Groundwater, Surfactants, Organochlorine Pesticides

\section{Introduction}

The synthetic detergents (or surfactants) and pesticides are the two most common group of chemical compounds that are increasingly being used in modern civilization. Surfactants are common contaminants of aquatic environments due to their large consumption in all types of washing and cleaning operations. Surfactants are chemical compounds that affects (usually reduces) surface tension when dissolved in water. As the production and human use of surfactants have increased manifolds in recent years, scientific studies have been intensified for better understanding on the transportation, toxicity and their chemical evolution process in aquatic environment.

Surfactants are synthetic compounds, characterised by a hydrophilic head and a lipophilic tail consisting of a Cbased linear or branched chain. The synthetic detergents prepared from polymers of ethylene oxides are resistant to biological attack because of their (C-O-C) bonds. The ions being smaller, remain less affected by the filtering action of soil. The most frequently applied surfactants are sodium salts of high molecular weight such as alkyl sulphates or sulphonates (LAS or linear C12 alkyl- benzene sulphonate). Surfactants generally have high biodegradability and have a moderate toxicity for fish. The threshold value which can impair aquatic life is $3-12$ $\mathrm{mg} / \mathrm{l}$ for anionic detergent, $3-38 \mathrm{mg} / \mathrm{l}$ for non-ionic detergent, and $20 \mathrm{mg} / 1$ for cationic detergent. In addition to affecting aquatic life, surfactants affect oxygen-turnover of water and reduce sedimentation process, and thus delaying water purification, particularly during aeration of waste water. Surfactants are also called methylene-blueactive substances (MBAS) because they produce colour change in aqueous solution of methylene blue dye.

The most widely used compound in detergent industry is sodium tri-polyphosphate (STP). Phosphates present in 
STP create deleterious effect on environment. Increased amount of phosphate is responsible for formation of large amount of algae in water. Common sewage treatment processes applied in municipal and industrial water cannot completely remove phosphates and nitrates. The appearance of anion active material in water may be an indication of potential viral pollution.

Pesticides are important input to modern agriculture and also used in public health in controlling communicable disease. During the last couple of decades, the use of pesticides has dramatically increased in India. However, the average pesticide consumption in India is still one of the lowest in the world at $0.5 \mathrm{~kg} /$ hectare against $10.7 \mathrm{~kg}$ in Japan and $4.5 \mathrm{~kg}$ in the US, mainly because of poor awareness among farmers and high cost of pesticides (Associated Indian Chamber of Commerce and Industry, Mint news, June 2008). The production of pesticides has increased from 5,000 to 85,000 metric tons between the period 1958 and 2004 [1]. The toxicity of these compounds poses risk to human health, environment and to the organisms which may not be targeted by pesticides. The effect of pesticides and their mobility depend upon their chemical and physical properties, soil characteristics, groundwater infiltrations and vadose zone behaviour, vegetation and local weather conditions. They resist degradation by chemical, physical or biological means. The degradation of DDT in soil is 75 to $100 \%$ in 4 to 30 years [2].

Organochlorine pesticides or OCPs are susceptible for fixation through food chain and can significantly magnify the original concentration to end-user. OCPs are lipid soluble, and hence cumulative bio-accumulation in the body fat of mammals might pose potential health hazard in the long run [3]. Chronic exposure to OCPs may lead to several dysfunctions of human system like, leukaemia, cancer, damage of lever and reproductive system [4,5]. Though the OCPs are banned in developed countries, in several developing countries they are still in use, like DDT and HCH were used until recently in India for agriculture as well as sanitary purposes. Groundwater contamination by pesticides is an issue of grave concern, particularly where drinking water supply is dependent on aquifers. It is estimated that annually 260 million litres of industrial wastes, run off from the 6 million tons of fertilizers and 9000 tons of pesticides used in agriculture within the Ganga Basin enters into the river [6].

Studies on OCPs in the ground and surface waters of the alluvial plain of upper-and mid-Ganga basin though available [2,6-10], little is known from the delta region specially in and around Kolkata, a large metropolis, known for numerous manufacturing industries, and a hinterland for paddy and cash crop cultivation in the Eastern India. The present investigation aims to make a quantitative evaluation of the anionic surfactants and
OCP residues in surface water and groundwater sources, viz., the river Hugli and its tributary, ponds, lakes, dug wells, hand pumps and bore wells, from Kolkata urban and its surrounding areas. The data presents an account of the level of concentration of the twin scourge of man made chemical hazard in a large metropolitan town and its neighbouring area along the river Hugli.

\section{Study Area}

The study area covers 1246 sq. km of Kolkata Metropolitan District (KMD) and adjoining Howrah, Hugli and 24 Paraganas (North \& South) districts, located on either side of the river Hugli and a few moribund tributaries like Saraswati (Figure 1). The population of Kolkata metropolitan area is 13.2 million (Govt. of India 2001). Situated at $130 \mathrm{~km}$ up the estuary of the river Hugli, the KMD is in the midst of intense agricultural activity thriving on the fertile tract of western part of the Ganga Delta in West Bengal state in India. The area represents a typical riverine tract surrounded by marshes, tidal creeks, mangrove, swamps and wetlands. The easterly flowing river Ganga swerves southward around the hill ranges of Rajmahal Flow (basalts, Lower Cretaceous) and bifurcates into two streams (Figure 1, inset), the south-east erly flowing Padma enters into Bangladesh and southerly flowing Bhagirathi flows down the Indian territory. The lower tidal reaches of the Bhagirathi is known as the Hugli River, which forms the life-line of KMD. The area receives an annual average rainfall of $1633.6 \mathrm{~mm}, 75 \%$ of which is contributed by southwest monsoon between June and September. Paddy is the main crop followed by potato and vegetables. Three crops are grown in the region, viz., monsoon (June to September), winter (October to February) and summer (March to May), with a cropping intensity of $162 \%$ (Govt of West Bengal 2008).

The study area forms a part of Lower Deltaic Plain of the Ganga river system, lying on both sides of the river Hugli (Figure 1, inset). Fluviatile sediments of Quaternary age made up of a succession of clay, sandy clay, silt and silty clay with occasional gravels underlies KMD [11-13]. The lithological sequence of the Kolkata Metropolitan Area and eastern part of Howrah district reveals a laterally persistent clay/sandy clay bed at the top of the sequence, having a thickness of 13.5 to $54.0 \mathrm{~m}$ (Figure 2) [14]. Thin fine sand lenses often interrupt the top clay/sandy clay sequence. Another prominent clay bed occurs between $300 \mathrm{~m}$ and $415 \mathrm{~m}$ below ground level (bgl). The sequence between the top and the basal clay is marked predominantly by sand of various size grades with occasional gravel and clay beds. Groundwater in this part occurs under semi-confined condition. The 


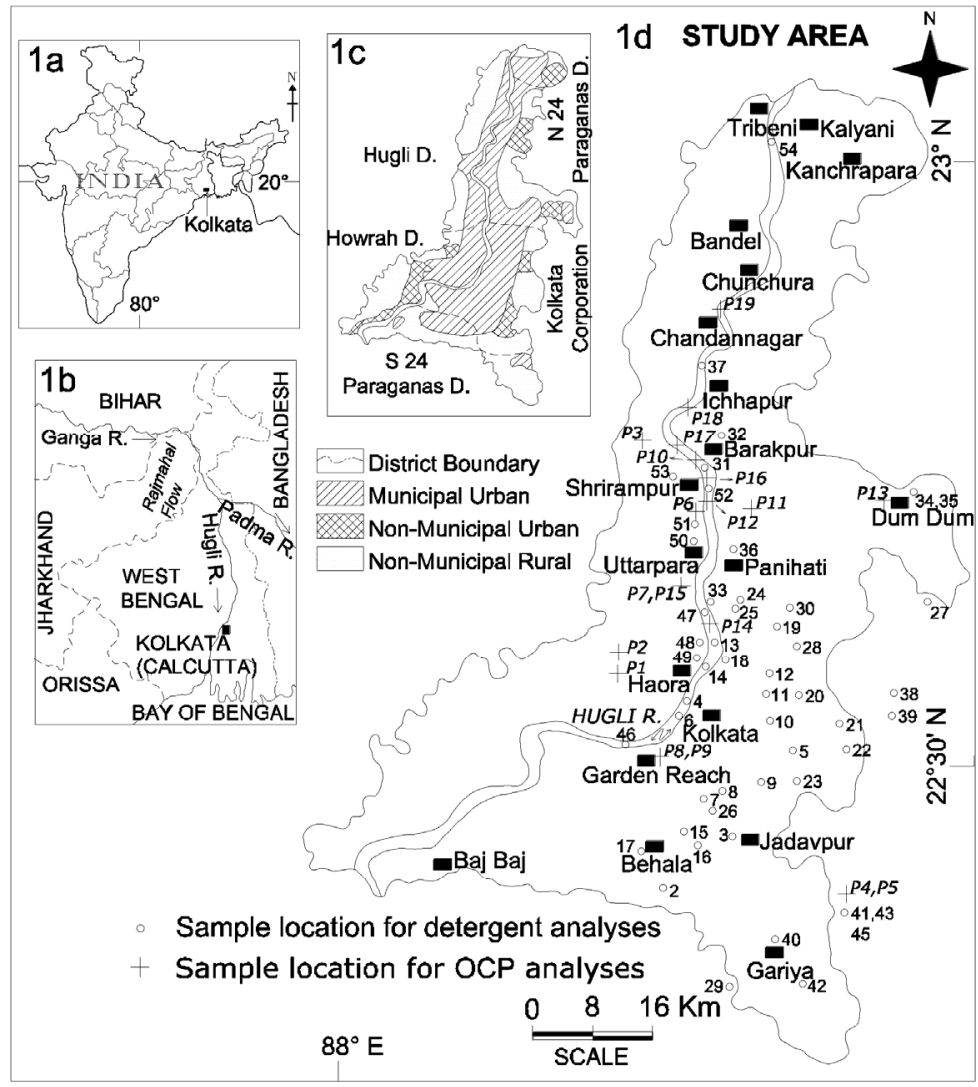

Figure 1. Location map of the study area. a) India, showing the location of West Bengal State. b) Bifurcation of the Ganga to southerly flowing Hugli River in India and easterly flowing Padma River in Bangladesh. c) Municipal and non-municipal areas showing the parts of the districts (Hugli, Howrah, North \& South 24 paraganas, Nadia) and Kolkata Corporation falling in KMD. d) Sample stations for organochlorine pesticides (cross) and anionic surfactants (circle) in KMD.

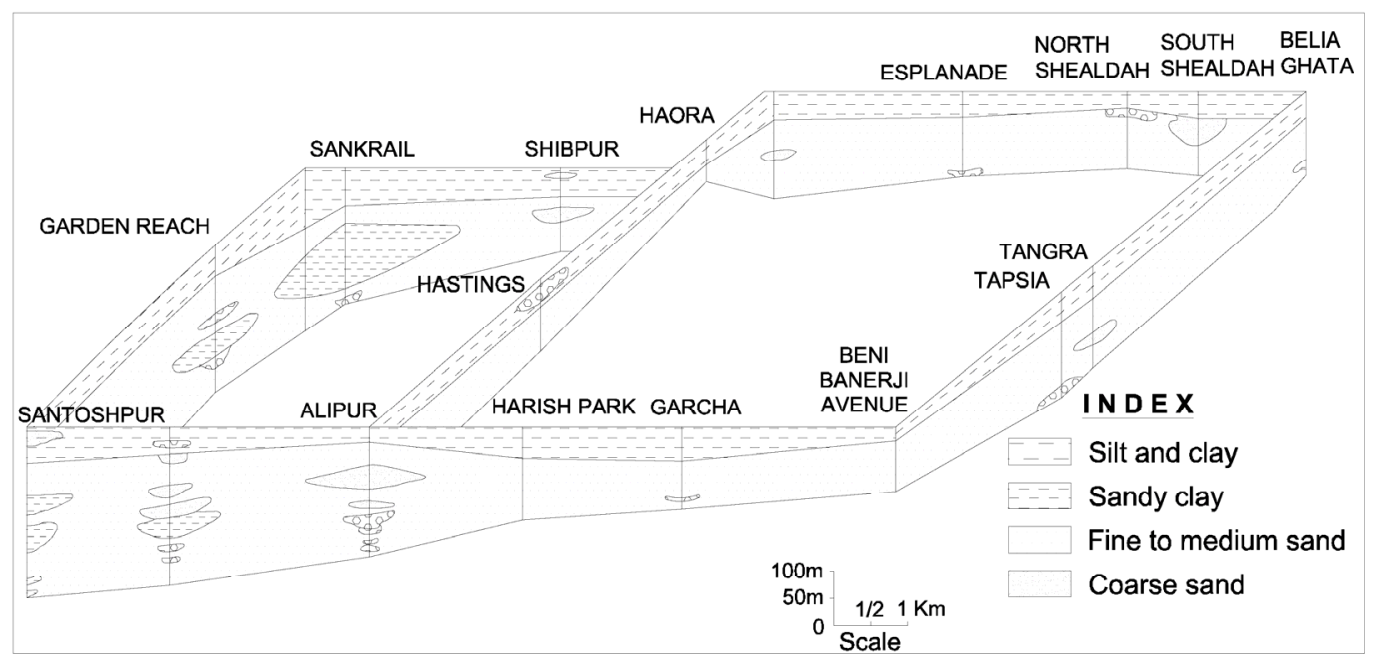

Figure 2. Fence diagram showing aquifer distribution of Kolkata urban area (after Biswas [14]).

principal productive zones usually tapped for municipal water supply ranges from $80 \mathrm{~m}$ to $160 \mathrm{~m} \mathrm{bgl}$. The hydraulic head of this aquifer varies from $0.5-1.0 \mathrm{~m}$ above mean sea level in the northern part of KMD which gradually goes deeper towards south. A groundwater trough is formed below the Kolkata metropolitan area, where the 
hydraulic head lies $10 \mathrm{~m}$ below msl as a result of overdraft to the tune of 73.5 million litre/day [13].

\section{Chemical Quality of Groundwater}

Wide variation in chemical quality of groundwater is observed in KMD within the studied depth of $200 \mathrm{~m} \mathrm{bgl}$. Analysis of chemical quality of groundwater was beyond the scope of this research. Published literature reveals that groundwater in greater Kolkata is mildly alkaline $(\mathrm{pH}$ 6.9-9.0), with total dissolved solids ranging from 368 to $3200 \mathrm{mg} / \mathrm{l}$, with an average of $1130 \mathrm{mg} / \mathrm{l}$ [15]. The anion chemistry is dominated by $\mathrm{Cl}$ and $\mathrm{HCO}_{3}$, both showing wide variation between $21-1320 \mathrm{mg} / \mathrm{l}$ and $210-666 \mathrm{mg} / \mathrm{l}$, respectively. Sulphate ranges between 0.2 and $140.7 \mathrm{mg} / \mathrm{l}$. Among cations, Na shows wider variation (42-640 mg/l) than Ca (27-269 mg/l). Analyses of groundwater quality through Piper diagram (Figure 3) [13] show; 1) equal dominance of strong $\left(\mathrm{Cl}, \mathrm{SO}_{4}\right)$ and weak $\left(\mathrm{HCO}_{3}\right)$ acids, and 2) marginal dominance of alkalis $(\mathrm{Na}, \mathrm{K})$ over alkaline earth $(\mathrm{Ca}, \mathrm{Mg})$. A study involving detailed analyses of some toxic trace elements, viz. $\mathrm{Cu}, \mathrm{Pb}, \mathrm{Zn}, \mathrm{Cd}, \mathrm{As}, \mathrm{Hg}$ and $\mathrm{Se}$ in groundwater of KMD [15], indicated that the level of concentration of these elements are less in deeper aquifer in comparison to the shallow aquifer. In general, the concentrations remain within the permissible limits for drinking use [16], except a few localised pockets where $\mathrm{Pb}, \mathrm{Cu}, \mathrm{Cd}$ and As have exceeded the limits be cause of infiltration from industrial effluents.

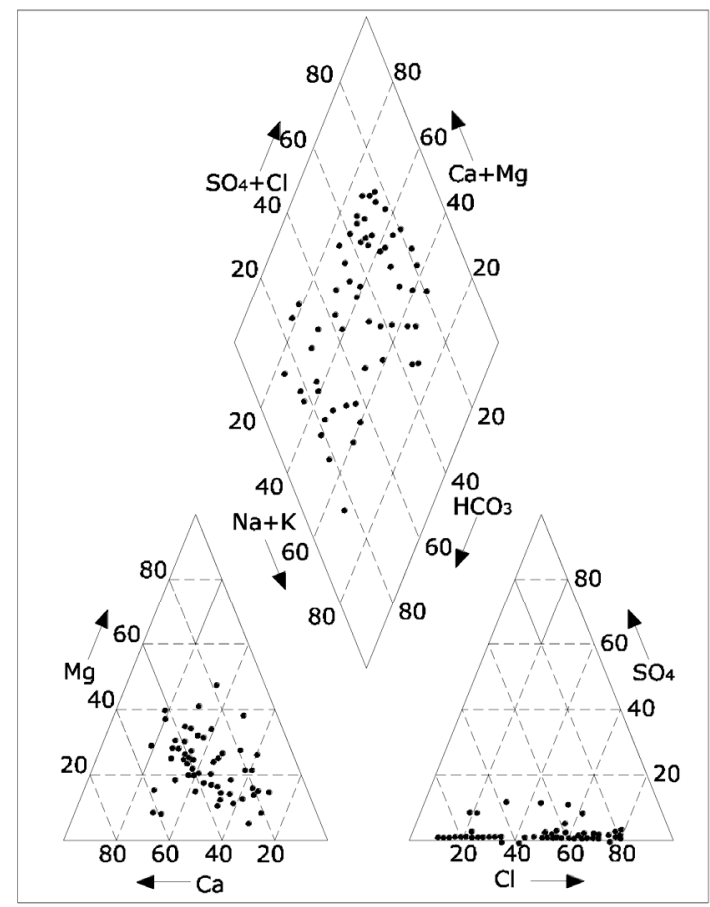

Figure 3. Piper diagram showing groundwater quality in Kolkata Municipal area (after Sikdar et al. 2001).

\section{Sample Collection}

Water samples have been collected from different sources representing both from surface water and groundwater sources. The groundwater samples are collected from hand pumps and tube wells tapping aquifers between $40 \mathrm{~m}$ and $180 \mathrm{~m} \mathrm{bgl}$. The sample have been collected from the outlets after flushing water for 10 minutes in case of hand pump, and 5 minutes in case of bore well, in order to obtain fresh aquifer water.

For anionic surfactant analysis, 54 samples have been collected (groundwater-27, tanks and other surface water accumulations-16, and river-11) during November (postmonsoon period) (Figure 1, Table 3). Samples for organochlorine pesticides or OCPs have been collected separately from 19 localities (Figure 1, Table 4). To study the seasonal variation in OCP concentrations, repeat samplings are made (except at Palta and Konnagar) in the month of May (pre-monsoon), August (monsoon) and post-monsoon (November) periods. Out of 52 samples collected for OCP investigations, 23 samples are from Hugli River between Chandannagar and Garden Reach, a stretch of about $40 \mathrm{~km}$, representing intense industrial activity (e.g. jute, chemical, automobile, steel, ammunition etc.) on either side of the river (Figure 1). Rest of the water samples have been collected from tanks, treated water from effluent treatment plant, a tributary of Hugli (Saraswati) and groundwater (collected from hand pumps).

For pesticide residue analysis sampling bottles made up of high quality dark glass with teflon stopper are used. Plastic or polyethylene containers are avoided as the pesticides present in water samples is likely to be adsorbed on inner walls of the bottles. Similar containers are used for synthetic detergent analysis as well. The unfiltered water samples for OCP analysis are processed following the standard method $[17,18]$. Locations of samples are indicated in Figure 1.

\section{Analytical Methods}

\subsection{Anionic Synthetic Detergent}

Methylene blue, a redox indicator forms a blue salt or ion pair when methylene blue, a cationic dye, reacts with any anionic surfactant, including linear alkyl sulphonate (LAS). The "Methylene blue" complex is extracted with chloroform and the intensity of the blue colour complex is measured at $652 \mathrm{~nm}$ using Varian Spectrophotometer, model DMS (Table 1). The reagents used are 1) stock linear alkyl-benzene sulphonate- $1 \mathrm{ml}=1000 \mu \mathrm{g}$ of the solution, 2) standard solution- $0.01 \mathrm{mg} / \mathrm{l}$ prepared by diluting $10 \mathrm{ml}$ stock solution $(1000 \mathrm{mg} / \mathrm{l})$ to $1: 1$ water, 3) chloroform AR, 4) methylene blue solution (0.1\%) AR, 5) phenolphthalein, and 6) concentrated sulphuric acid. 
Table 1. Methods adopted, instruments used and detection limits for surfactants and OCP analysis.

\begin{tabular}{|c|c|c|c|c|}
\hline Sl No & Parameters & Method & Instruments used & Detection limits (mg/l/ $/ \mathrm{g} / \mathrm{l})$ \\
\hline 1 & Anionic surfactants & Ion-Pair method & Spectrophotometer & $0.01 \mathrm{mg} / 1$ \\
\hline 2 & Aldrin & Extraction method with n-Hexane & GLC & $0.05 \mu \mathrm{g} / 1$ \\
\hline 3 & Dieldrin & -do- & -do- & $1.0 \mu \mathrm{g} / 1$ \\
\hline 4 & Haptachlor & - do- & - do- & $0.05 \mu \mathrm{g} / 1$ \\
\hline 5 & P,P'-DDE:DDT & - do- & -do- & $0.1 \mu \mathrm{g} / 1$ \\
\hline 6 & P,P'-TDD (total) & -do- & -do- & $0.1 \mu \mathrm{g} / 1$ \\
\hline 7 & P,P'-DDT (isomer) & - do- & - do- & $0.1 \mu \mathrm{g} / 1$ \\
\hline 8 & HCH (lindane) & - do- & -do- & $0.1 \mu \mathrm{g} / 1$ \\
\hline
\end{tabular}

The intensity of the colour is proportional to the quantity of 'MBAS' (methylene blue active substance) present in the sample, the concentration of which in water is calculated from the calibration curve [17]. Sensitivity-0.025 mg MBAS/litre calculated as LAS. The optimal conditions of analytical method and detection limits are given in Table 1.

\subsection{Organochlorine Pesticides}

OCP residues are extracted from water samples after treating with acetonitrile. Resulting solution has been extracted several times with n-hexane. The hexane extract is filtered through anhydrous sodium sulphate and subjected to Gas Liquid Chromatography (GLC, model 5700, Nucon) analysis [19]. All reagents used are of analytical grade. Nitrogen gas is employed as the carrier gas (flow rate $50 \mathrm{ml} / \mathrm{min}$ ) and makeup gas, and the injection technique has been in split mode. Analysis has been done at the linearity region of the detector for particular constituent. The GLC conditions adopted in the laboratory are-1) oven temperature $-195^{\circ} \mathrm{C}, 2$ ) injector temperature- $235^{\circ} \mathrm{C}$, and 3) detector temperature- $245^{\circ} \mathrm{C}$. Detection limits of different OCPs are given in Table 1 and their retention time in Table 2.

\section{Results and Discussions}

\subsection{Synthetic Detergents}

Higher values of surfactant cause skin irritation [20]. The threshold value that can impair aquatic life is 3-12 $\mathrm{mg} / \mathrm{l}$. The range and average (parenthesis) values of MBAS, calculated as linear alkyle sulfonate, for surface and groundwater are, $0.025-0.425(0.149) \mathrm{mg} / \mathrm{l}$ and 0.015-0.084 (0.032) mg/l (Table 3). Sector-wise, the surfactant values in the groundwater and surface waters are $0.015-0.052(0.29) \mathrm{mg} / \mathrm{l}$ and $0.25-0.425(0.148)$ $\mathrm{mg} / \mathrm{l}$ for Kolkata (urban); 0.15-0.84 (0.42) $\mathrm{mg} / \mathrm{l}$ and 0.028-0.075 (0.059) mg/l for 24 Paraganas (North and South) districts in the south (representing semi-urban and rural); and 0.018-0.035 (0.025) $\mathrm{mg} / \mathrm{l}$ and 0.07-0.125
Table 2. Retention time of various pesticide residue.

\begin{tabular}{lc}
\hline \multicolumn{1}{c}{ Pesticides } & Retention time (minute) \\
\hline$\alpha$ - $\mathrm{HCH}$ & 1.31 \\
$\beta-\mathrm{HCH}$ & 2.07 \\
$\gamma-\mathrm{HCH}$ (lindane) & 1.72 \\
$\mathrm{~S}-\mathrm{HCH}$ & 2.33 \\
pp'-DDE & 6.82 \\
pp-DDT: DDT & 13.08 \\
pp'-TDE: (total) & 10.55 \\
pp'-DDT: (isomers) & 12.77 \\
Op'-DDT: & 9.68 \\
Aldrin & 2.88 \\
op'-Dicofol & 4.02 \\
pp'-Dicofol & 4.08 \\
Heptachlore & 4.08 \\
\hline
\end{tabular}

(0.90) $\mathrm{mg} / \mathrm{l}$ for Howrah and Hugli districts in the north (semi-urban) respectively (Figure 1, Table 3 ).

Highest concentration of surfactants is noted in surface water from the Hugli River, near Howrah Bridge (0.425 $\mathrm{mg} / \mathrm{l})$, and lowest in the groundwater at Chetla in central Kolkata $(0.015 \mathrm{mg} / \mathrm{l})$, drawn from a hand pump reaching to a depth of $75 \mathrm{~m}$ (Table 3 ). As expected, groundwater in general, shows lower concentration of surfactants in comparison to surface water. Maximum concentration of surfactant in groundwater is recorded at Mathurapur $(0.084 \mathrm{mg} / \mathrm{l})$ from a rural area in the southernmost part of South 24 Paraganas (Table 3, Figure 1). The study reveals a range of surfactant value from 0.013 to 0.425 $(0.118 \mathrm{mg} / \mathrm{l})$ in the river Hugli, and 0.017 to $0.250(0.09)$ $\mathrm{mg} / \mathrm{l}$, in the ponds and tanks. A desirable limit of 0.2 $\mathrm{mg} / \mathrm{l}$ and maximum permissible limit as $1.0 \mathrm{mg} / \mathrm{l}$ of surfactant in water have been adopted in India (Bureau of Indian Standards 1991). The anionic surfactant values in surface and groundwater of Calcutta Metropolitan District (CMD) exceed the desirable limit at some places; however, they are well within the maximum permissible limit for drinking use. Lower concentration of anionic detergent in groundwater (av. $0.035 \mathrm{mg} / \mathrm{l}$ ) in comparison to river waters or tanks may possibly be due to low hydraulic conductivity of the top clay/sandy clay sequence, which is regionally behaving as an aquitard. 
Table 3. Synthetic detergent concentration (mg/l) of surface water and groundwater in Greater kolkata.

\begin{tabular}{|c|c|c|c|}
\hline Sl No. & Sample locality & Water source & $\begin{array}{c}\text { Surfactant } \\
\text { concentration }(\mathrm{mg} / \mathrm{l})\end{array}$ \\
\hline 1 & Rash Behari Avenue & Groundwater $^{1}$ & 0.018 \\
\hline 2 & Thakur Pukur & Tank water $^{2}$ & 0.250 \\
\hline 3 & Jadavpur & Tank water $^{2}$ & 0.028 \\
\hline 4 & Near Howrah bridge & Hugli River water ${ }^{3}$ & 0.425 \\
\hline 5 & Subash Sarobar, Beleghata & Tank water $^{2}$ & 0.205 \\
\hline 6 & Babu ghat (Central Kolkata) & Hugli River water ${ }^{3}$ & 0.185 \\
\hline 7 & Rabindra Sarobar, south Kolkata & Tank water ${ }^{2}$ & 0.200 \\
\hline 8 & Kalighat & Tank water ${ }^{2}$ & 0.150 \\
\hline 9 & Bondal Road & Tank water $^{2}$ & 0.020 \\
\hline 10 & Park Street & Groundwater $^{1}$ & 0.018 \\
\hline 11 & College Square & Tank water $^{2}$ & 0.105 \\
\hline 12 & Hedua, near Beedon Street & Tank water ${ }^{2}$ & 0.094 \\
\hline 13 & Beniatola Ghat & Hugli River water ${ }^{3}$ & 0.025 \\
\hline 14 & Nimtola Ghat (north Kolkata) & Hugli River water ${ }^{3}$ & 0.034 \\
\hline 15 & Tollyganj & Groundwater $^{1}$ & 0.035 \\
\hline 16 & Lake Gardens & Groundwater $^{1}$ & 0.027 \\
\hline 17 & Behala & Groundwater $^{1}$ & 0.025 \\
\hline 18 & Bag Bazar (Kasi Mitra Ghat) & Hugli River water ${ }^{3}$ & 0.165 \\
\hline 19 & Belgachia & Groundwater $^{1}$ & 0.022 \\
\hline 20 & Chitpur & Groundwater $^{1}$ & 0.022 \\
\hline 21 & Tiljola & Groundwater $^{1}$ & 0.022 \\
\hline 22 & Dhapa (site of municipal waste disposal) & Groundwater $^{2}$ & 0.052 \\
\hline 23 & Park Circus & Groundwater $^{1}$ & 0.028 \\
\hline 24 & Bowbazar & Groundwater $^{1}$ & 0.039 \\
\hline 25 & Beniapukur & Groundwater $^{1}$ & 0.020 \\
\hline 26 & Chetla & Groundwater $^{1}$ & 0.015 \\
\hline 27 & Baguihati & Tank water ${ }^{2}$ & 0.017 \\
\hline 28 & Raja Bajar & Groundwater $^{1}$ & 0.045 \\
\hline 29 & Bansdroni & Groundwater $^{1}$ & 0.045 \\
\hline 30 & Coshipur & Groundwater $^{1}$ & 0.032 \\
\hline 31 & Barrackpur & Hugli River water ${ }^{3}$ & 0.053 \\
\hline 32 & Palta & Canal water ${ }^{2}$ & 0.073 \\
\hline 33 & Dakhineswar & Tank water ${ }^{2}$ & 0.064 \\
\hline 34 & Dum Dum & Tank water $^{2}$ & 0.075 \\
\hline 35 & Dum Dum & Groundwater $^{1}$ & 0.043 \\
\hline 36 & Belgharia (near Texmaco) & Tank water ${ }^{2}$ & 0.038 \\
\hline 37 & Naihati & Hugli River water ${ }^{3}$ & 0.075 \\
\hline 38 & Salt Lake City (Sech Bhawan) & Groundwater $^{1}$ & 0.015 \\
\hline 39 & Salt Lake City (Tank No.13) & Groundwater $^{1}$ & 0.025 \\
\hline 40 & Garia & Groundwater $^{1}$ & 0.028 \\
\hline 41 & Sonarpur & Groundwater $^{1}$ & 0.065 \\
\hline 42 & Narendrapur (R.K. Mission) & Tank water ${ }^{2}$ & 0.028 \\
\hline 43 & Sonarpur & Tank water ${ }^{2}$ & 0.060 \\
\hline 44 & Mathurapur & Groundwater $^{1}$ & 0.084 \\
\hline 45 & Sonarpur & Groundwater $^{1}$ & 0.058 \\
\hline 46 & Garden Reach & Hugli River water ${ }^{3}$ & 0.034 \\
\hline 47 & Balikhal & $\begin{array}{l}\text { Tributary of Hugli River } \\
\text { (carries domestic sewage) }\end{array}$ & 0.080 \\
\hline 48 & Belur & Groundwater $^{1}$ & 0.022 \\
\hline 49 & Lilua & Groundwater $^{1}$ & 0.018 \\
\hline 50 & Uttrapara & Groundwater $^{1}$ & 0.070 \\
\hline 51 & Rishra & Groundwater $^{1}$ & 0.035 \\
\hline 52 & Srirampur & Hugli River water $^{3}$ & 0.085 \\
\hline 53 & Seoraphuli & Groundwater $^{1}$ & 0.025 \\
\hline 54 & Bansberia & Hugli River water ${ }^{3}$ & 0.013 \\
\hline
\end{tabular}

${ }^{1}$ Drinking use, ${ }^{2}$ Community use other than drinking, ${ }^{3}$ Used for drinking after treatment. Analyst: T. K. Chatterjee 
Various proposals have been made to replace phosphates in detergents by other substances, viz., citric acid, nitrilotriacetic acid (NTA), EDTA, zeolite (sodium alumino-silicate) etc. Although toxicological data for NTA are incomplete, they indicate a potential human hazard because NTA alters the toxicity of metals by affecting their entry in body, as well as their distribution and concentration in the tissues [21]. Pending further toxicological evaluation, the US government has recommended that NTA detergents should not be used.

\subsection{Organochlorine Pesticide}

The OCPs used in agriculture or in urban areas are transported from their target site and enter into aquatic environment via infiltration, air-drift and surface run-off, affecting the eco-systems [22]. The end destination of OCPs in aquatic system is groundwater, through percolation through the vedose zone, where their transformation products may remain for years [23]. The recommended total pesticide level for drinking water to be less than $0.5 \mu \mathrm{g} / 1$, and individual pesticide not more than $0.1 \mu \mathrm{g} / 1$ [24]. The analytical results of the presence of OCP both in surface water and groundwater in the study area are given in Table 4 . The pesticide residues detected are lindane, other isomers of $\mathrm{HCH}$, aldrin and dieldrine, dicofel, heptachlor and DDT (total isomers). Among the various pesticide groups-lindane, $\mathrm{HCH}$, aldrin and DDT are detected in the Hugli River stretching between Chandannagar and Garden Reach. Similar accumulation of pesticide residues was noticed in other surface water bodies like tanks, lakes and in a tributary (Saraswati river). Interestingly, heptachlor is not detected in the Hugli River. Only lindane is detected in surface water from Baksara and Andul, whereas at Sonarpur and Uttarpara a wide range of pesticide residues has been recorded (Table 4). Groundwater samples collected from two localities, viz., Sonarpur and Palta, revealed presence of all the pesticide groups under investigation, but in lesser quantity.

$\gamma-\mathrm{HCH}$, also called as lindane, is found to be most commonly detected pesticide in all types of water sources studied. Presence of lindane indicates its widespread use in agriculture, because of its effectiveness, long-lasting impact, and its use for human vector control. Production of lindane is banned in many countries because of its potential health hazards, but China, Romania and India is still producing [25]. In India, 40 Metric Ton of lindane was produced in 1996-97 [26]. The agricultural use of lindane is diminishing, but no authentic data is available on present level of production. Higher incidence of lindane residue from the groundwater has been reported from the upper part of the Ganga basin [2,7,9]. Heptachlor has been detected rarely, indicating its limited application.
The tolerance limit of some individual pesticide residue for human consumption is: $\gamma-\mathrm{HCH}$ (lindane)-2.0 $\mu \mathrm{g} / \mathrm{l}$, aldrin and dieldrin- $0.03 \mu \mathrm{g} / \mathrm{l}$, heptachlor/ heptachlor epoxide- $0.03 \mu \mathrm{g} / 1$ and DDT (total isomers) $-2.0 \mu \mathrm{g} / 1$ [21]. The concentration of lindane in surface water or groundwater always remained within tolerable limit. The concentration of aldrin and dieldrin are recorded beyond the permissible limit in the surface waters from the Hugli River at Seoraphuli and Barrackpur (serial nos.10, 17 Table 4).

DDT is widely detected pesticide from different types of sources after lindane. Bioaccumulation potential of DDT is known for its high fat solubility. Its presence in lower levels passes into food chain (soil-water-plant-man). DDT concentration has not exceeded the permissible limit [21], highest concentration being $1.4 \mu \mathrm{g} / \mathrm{l}$, is found at Sonarpur, a rural area in the south 24 Paraganas district, in winter season. The reason may be accumulation of surface run-off into the tank (pond) from the adjoining localities. Aldrin and dieldrine remain within permissible limit of $0.03 \mu \mathrm{g} / \mathrm{l}$, except at the Hugli River water at Seoraphuli (sample no 17). Heptachlor and dicofel have been detected in a few localities. In canal water sample at Palta (Sample no 11) heptachlor has exceeded the limit for drinking use. The Hugli River water has been found to be free from these two pesticides.

The water supply in the study area is largely dependent on treated surface water from the Hugli River. Groundwater drawn by deep tube wells and hand pumps are also used for drinking, particularly the outskirts of Kolkata, Hugli and Howra districts, without treatment. The groundwater samples analysed essentially represent drinking water source, except sample no 22, which is a hand pump used other than drinking (Table 3). The tanks are for community used for ablution and drinking for cattle. No water source used for drinking was found to be contaminated.

In surface waters, the pesticide concentrations are found maximum in winter due to its greater application, and minimum in monsoon (rainy season) due to its limited use and dilution. Again their abundance showed marginally higher in summer (May-June) than in the monsoon (June-September). In contrast, the seasonal variation of OCPs in the groundwater showed highest concentration during monsoon and lowest in the summer in conformity with the observations made elsewhere (viz. Kanpur and Unnao) from the upper Ganga basin $[2,9]$. This feature may be related to infiltration of surface water charged with pesticides to aquifer system during monsoon. Detection of lindane, $\mathrm{HCH}$, eldrine and dieldrine, heptachlor and DDT in the groundwater supports the above contention. These observations are in contrast from the findings of toxic trace elements (viz. $\mathrm{Cu}, \mathrm{Pb}, \mathrm{Zn}$, $\mathrm{Cd}, \mathrm{As}, \mathrm{Hg}$ and $\mathrm{Se}$ ) in the groundwater of Kolkata urban area, where the level of concentrations are maximum in 
Table 4. Range of pesticide concentration of water in summer, winter and rainy seasons in Greater Kolkata ( $\mu \mathrm{g} / \mathrm{l})$. (Figures in brackets indicate mean value).

\begin{tabular}{|c|c|c|c|c|c|c|c|c|c|}
\hline SI No & Location & $\begin{array}{l}\text { No. of } \\
\text { sample }\end{array}$ & Source & Lindane & $\begin{array}{c}\text { Other isomer } \\
\text { of HCH }\end{array}$ & $\begin{array}{l}\text { Aldrin and } \\
\text { dieldrin }\end{array}$ & Heptachlor & Dicofel & $\begin{array}{c}\text { DDT } \\
\text { (total isomers) }\end{array}$ \\
\hline 1 & Baksara, Howrah & 3 & TW & $0.28-0.3(0.29)$ & -nd- & -nd- & -nd- & -nd- & -nd- \\
\hline 2 & Andul, Howrah & 3 & TW & $0.35-0.37(0.36)$ & -nd- & -nd- & -nd- & -nd- & -nd- \\
\hline 3 & Saraswati river & 3 & RW & -nd- & -nd- & -nd- & -nd- & $0.02-0.03(.02)$ & -nd- \\
\hline 4 & Sonarpur & 3 & GW & -nd- & -nd- & $0.01-0.03(0.02)$ & -nd- & $0.02-0.03(.02)$ & -nd- \\
\hline 5 & Sonarpur & 3 & TW & $0.05-0.1(0.08)$ & $2.1-9.9(5.5)$ & -nd- & -nd- & $3.03-14.03(8.2)$ & $0.8-1.4(1.07)$ \\
\hline 6 & Konnagar, Hugli & 1 & TW & & 0.18 & -nd- & -nd- & 37.42 & 0.01 \\
\hline 7 & Balikhal, Howrah & 3 & RW & $0.04-0.05(0.045)$ & $0.02-0.04(0.03)$ & $0.02-0.03(0.02)$ & -nd- & -nd- & $0.04-.08(0.06)$ \\
\hline 8 & Garden Reach & 3 & RW & & $0.12-0.2(0.15)$ & $0.01-0.03(0.02)$ & -nd- & -nd- & $0.03-0.1(0.07)$ \\
\hline 9 & Garden Reach & 3 & TW & $0.01-0.07(0.43)$ & $0.07-0.14(0.1)$ & $0.01-0.01(0.01)$ & -nd- & -nd- & $0.04-0.12(0.08)$ \\
\hline 10 & Barackpur & 3 & RW & $0.22-0.35(0.3)$ & $5.4-6.65(6.01)$ & $0.7-0.9(0.8)$ & -nd- & -nd- & $0.05-0.12(0.09)$ \\
\hline 11 & Palta & 1 & $\mathrm{CW}$ & 0.43 & 7.82 & -nd- & 0.05 & -nd- & 0.11 \\
\hline 12 & Palta & 2 & GW & $0.1-0.3(0.2)$ & -nd- & -nd- & $\begin{array}{l}0.01-0.01 \\
(0-01)\end{array}$ & -nd- & $0.3-0.5(0.02)$ \\
\hline 13 & Dumdum & 3 & TW & -nd- & -nd- & $0.01-0.03(0.02)$ & -nd- & -nd- & -nd- \\
\hline 14 & Dakhineswar & 3 & RW & $0.05-0.1(0.077)$ & $0.1-0.2(0.15)$ & $0.01-0.03(0.02)$ & -nd- & -nd- & $0.5-0.65(0.56)$ \\
\hline 15 & Uttarpara & 3 & RW & $0.03-0.08(0.06)$ & $0.02-0.06(0.04)$ & $\begin{array}{c}0.01-0.02 \\
(0.015)\end{array}$ & -nd- & -nd- & $0.2-0.5(0.33)$ \\
\hline 16 & Srirampur & 3 & RW & $0.02-0.05(0.033)$ & $\begin{array}{c}0.02-0.05 \\
(0.033)\end{array}$ & $\begin{array}{c}0.01-0.03 \\
(0.021)\end{array}$ & -nd- & -nd- & $0.2-0.4(0.3)$ \\
\hline 17 & Seoraphuli & 3 & RW & $0.25-0.5(0.38)$ & $4.2-5.5(4.9)$ & $0.02-0.04(0.03)$ & -nd- & -nd- & $0.1-0.2(0.15)$ \\
\hline 18 & Kamarhati & 3 & RW & $0.01-0.04(0.027)$ & -nd- & $\begin{array}{c}0.01-0.025 \\
(0.018)\end{array}$ & -nd- & -nd- & $0.01-0.2(0.18)$ \\
\hline 19 & Chandannagar & 3 & RW & $0.02-0.05(0.033)$ & $0.2-0.3(0.25)$ & $\begin{array}{c}0.01-0.02 \\
(0.018)\end{array}$ & -nd- & -nd- & $0.3-0.6(0.47)$ \\
\hline
\end{tabular}

TW-Tank water, RW-River water, CW-Canal water, GW- Groundwater, TW-Treated water of effluent plant, nd- Not detected

summer and minimum in monsoon due to dilution [15].

\section{Conclusions and Recommendations}

Anionic synthetic detergent is detected in all surface water and groundwater samples. In no samples, however, it has exceeded the guideline for drinking use $(1.0 \mathrm{mg} / \mathrm{l})$ prescribed by the Bureau of Indian Standards (1991). Relatively higher load in the Hugli River (0.013-0.425 $\mathrm{mg} / \mathrm{l})$ indicates that the river receives untreated domestic sewage from the urban centres located along the banks. The tanks and ponds are showing higher values than groundwater as they are used for ablution and washing of clothes.

The study reveals that Lindane $(0.01-0.37 \mu \mathrm{g} / \mathrm{l})$ is the most commonly detected pesticides in all types of sources, followed by DDT (0.01-1.4 $\mu \mathrm{g} / \mathrm{l})$ indicating their wide use for agriculture and human vector control. Nowhere the value exceeded the guidelines for drinking use prescribed by the World Health Organisation [21]. Aldrin and di-aldrin are detected both in the surface water and groundwater. The values remained beyond the limit prescribed for drinking use from the Hugli River at
Seoraphuli and Barrackpore. These two urban centres face each other across the river, $20 \mathrm{~km}$ north of Kolkata, dotted with a number of chemical, jute and liquor factories. The toxic effect of pesticides even present in traces on prolonged consumption is easily concentrated through the food chain, which should not be underestimated. The level of concentration of OCPs in water bodies in most of the area surveyed though remained within the limits prescribed by the World Health Organisation [21], their use should be controlled and replaced by suitable formulation of short-lived pesticides like organophosphates and carbamates that are relatively expensive, and regularly monitored as a measure for preventing health problems.

Groundwater in Greater Kolkata is safe considering the synthetic anionic detergents and OCPs. Relatively high load of synthetic detergent and OCPs like aldrin and dieldrine in patches of the Hugli River indicates that optimum care should be taken for treatment of the river water before supplying. Detection of these constituents in a few hand pump samples indicate seepage from surface sources through the top fine grained layer where it is sandy or silty, rendering localised higher vertical per 
meability.

\section{Acknowledgements}

The present work is an outcome of a major programme on the assessment of quality of ground and surface water in Eastern India undertaken by one of the authors (NCG). This paper is dedicated in the fond memory of Dr. T. K. Chatterjee, a sagacious chemist, who carried out the laboratory work with great zeal and enthusiasm at the Central Food Laboratory, Kolkata, prior to his untimely death. Critical reviews of the manuscript by A. K. Mukherjee of Indian Institute of Sciences, Bangalore and encouragement received from B. Prasad, Department of Chemistry, B. N. Mandal University and P. C. Chandra, Central Ground Water Board are gratefully acknowledged. The views expressed in the paper are independent and not related to any affiliated department of the author.

\section{References}

[1] P. K. Gupta, "Pesticide Exposure-Indian Scene," ElSevier Ireland Ltd, 2004.

[2] N. Sankaramakrishnan, A. K. Sharma and R. Sanghi, "Organochlorine and organophosphorous pesticides residues in groundwater and surface waters of Kanpur," Uttar Pradesh, India. Environment International, Vol. 31, pp. 113-120, 2005.

[3] IARC, "Occupational exposure in insecticide application, and some pesticides," International Agency for Research on Cancer, Lyon, (IARC monographs on the evaluation of Carcinogenic Risks to humans, v-53), 1991.

[4] V. K. Dua, R. Kumari, V. P. Sharma and S. K. Subbarao, "Organochlorine residues in human blood from Nainital (UP)," India. Bull Environ Contam Toxicol, Vol. 67, pp. 42-45, 2001.

[5] UNEP, "Global report on regionally based assessment of persistent toxic substances," UNEP Chemicals. Geneva, Switzarland, 2003.

[6] K. P. Singh, A. Malik, D. Mohan and S. Sinha, "Persistant organochlorine pesticide residue in alluvial groundwater aquifers of Ganga Plain," India. Bull Env Cont Toxico, 2005

[7] S. P. Mohapatra, M. Kumar, V. T. Gajbhiye and N. P. Agnihotri, "Groundwater contamination by organochlorine insecticide residues in a rural area in the Indo-Gangetic Plain," Environ Mon Assess, Vol. 35, pp. 155-164, 1995.

[8] S. Kumar, K. P. Singh and K. Gopal, "Organochlorine residues in rural drinking water sources of Northern and North Eastern India," J Envirnon Sci Health, Vol. 30, pp. 1211-1222, 1995.

[9] R. Sanghi and K. S. Sasi, "Pesticides and heavy metals in agricultural soil of Kanpur," India. Bull Environ Contam Toxicol, Vol. 67, pp. 446-454, 2001.

[10] R. P. Singh, "Comparison of organochlorine pesticide levels in soil and groundwater of Agra," India. Bull Envirno Contam Toxicol, Vol. 67, pp. 126-132, 2001.

[11] G. C. Chatterjee, A. B. Biswas, S. Basu and B. N. Niyogi, "Geology and groundwater resources of the greater Calcutta Metropolitan area," West Bengal, Bull Geol Surv India, Ser B No21, pp.150, 1964.

[12] A. B. Biswas and A. K. Saha, "Environmental hazards of the recession of piezometric surface of groundwater under Calcutta," Proc. Ind Nat Sc Aca, Vol. 51, No. 3, pp. 610-621, 1985.

[13] P. K Sikdar, "Geology of the Quaternary aquifers of the twin city of Calcutta-Howra," Jour Geol Soc Ind, Vol. 56, pp. 169-181, 2001.

[14] A. B. Biswas, "Water supply in Calcutta "Calcutta, the Live City' v.2, ed. Sukanata Choudhury," Oxford University Press, Kolkata, pp. 160-166, 1990.

[15] N. C Ghose, T. K. Chatterjee, A. Gupta and Saha. Dipankar "Heavy metal concentration in groundwater of Greater Calcutta (Kolkata)," West Bengal, India. Indian Jour. Geol. Vol. 73, pp. 55-56, 2001.

[16] BIS, "Drinking water quality standards. Bureau of Indian Standards," No. 10500, New Delhi, India, 1991.

[17] APHA, "Standard method for the examination of water and wastewater," American Public Health Association, New York, 1984.

[18] AOAC, "Official methods of analysis of the association of official analytical chemists. 16th Ed. Cunniff P (ed.)," 1995.

[19] W. Fresenius, K. E. Quentime and W. Schneider, "Water analysis," Springer Verlag, Berlin, pp. 804, 1988.

[20] H. P. Ciuetha and K. T. Dood, "The determination of the irritancy potential of surfactants using various methods of assessment," Drug Chem. Toxocol, Vol. 3, pp. 305-324, 1978.

[21] WHO, "Drinking water standards," World Health Organisation, Geneva, 1993.

[22] G. M. Rand, P.G. Wells and L. S. McLarti, "Introduction to acquatic toxicology," In. Rand GM ed., Tailor \& Francis, 1995.

[23] A. C. Belfroid, M. van Drunen, M. A. Beck, S. M. Schrap, C. A. M. van Gestel and B. van Hattum, "Relative risk of transformation products of pesticides for aquatic ecosystem," Sci Total Environ, Vol. 222, pp.167-183, 1998.

[24] EEC directive, Europian Economic Commission directive 3-76/464/EEC; EUROPA, 1980.

[25] M. Dutta and K. S. Schafer, Lindane, International POP Estimation Network," www.ipen.org, 2003.

[26] S. C. Mathur, "Pesticide industry in India," Pestic Inf XXIII, Vol. 4, pp. 17-29, 1998. 